Article received on 16 October 2013

Article accepted on 30 November 2013

UDC

\title{
MUSICA INHUMANA: TOWARDS THE POSTHUMANISTIC ETHICAL AND AESTHETICAL PARADIGM IN MUSIC*
}

\author{
Andrija Filipović \\ University of Arts in Belgrade \\ Interdisciplinary Studies \\ Theory of Arts and Media
}

\begin{abstract}
This paper deals with the analysis of noise music by the Japanese artist Merzbow, especially emphasizing the posthumanistic ethical and aesthetical paradigm as his artistic and political project. This project, or assemblage, has several aspects, three being particularly important: 'musical' system (acoustic material, creator, listener), visual and textual material (album covers, articles and interviews), and the attitude towards the nonhuman (machines, animals, nature in general). These three aspects are a particular assemblage that enables the critique of the "everyday body" and the contemporary society, by creating special aesthetics of existence and lines of flight, an aesthetics which, ultimately, removes the human subject and replaces it with an (in)organic multiplicity.
\end{abstract}

Key words: noise, Merzbow, masochism, posthumanism, aesthetics of organization

The main claim of this paper is that the analysis of noise music by Masami Akita, also known as Merzbow, can result in what I call posthumanistic ethical and aesthetical paradigm in art. In other words, his music and lifestyle create a particular assemblage with an undeniable political project at its centre, i.e. this assemblage produces specific lines of flight, ${ }^{1}$ both with respect to the

\footnotetext{
${ }^{*}$ The author contact addres: fil.andrija@gmail.com

This study was carried out within the project Identiteti srpske muzike u svetskom kulturnom kontekstu [Identities of Serbian Music in the World Cultural Context] (Reg. No. 177019) by the Department of Musicology at the Faculty of Music in Belgrade, supported by the Ministry of Education and Science of the Republic of Serbia

${ }^{1}$ Line of flight (ligne de fuite) is a notion that "defines the practical orientation of Deleuze's philosophy" in the sense that what determines a certain situation is the distribution of possibilities, i.e. "the spatio-temporal division of existence (roles, functions, activities, desires,
} 
Filipović, A.: Musica Inhumana: Towards the Posthumanistic Ethical ... (86-101)

'everyday' body as described by phenomenology and with respect to contemporary (post)capitalist consumer society. An assemblage (agencement), for Gilles Deleuze and Félix Guattari, is a set of multiplicities: "On a first, horizontal axis, an assemblage comprises two segments, one of content, the other of expression. On the one hand it is a machinic assemblage of bodies, of actions and passions, an intermingling of bodies' reactions to one another; on the other hand it is a collective assemblage of enunciation, of acts and statements, of incorporeal transformations attributed to bodies. Then on a vertical axis, the assemblage has both territorial sides, or reterritorialized sides, which stabilize it, and cutting edges of deterritorialization, which carry it away. [...] Its territoriality (content and expression included) is only a first aspect; the other aspect is constituted by lines of deterritorialization that cut across it and carry it away. These lines are very diverse: some open the territorial assemblage onto other assemblages (for example, the territorial refrain of the animal becomes a courtship or group refrain). Others operate directly upon the territoriality of the assemblage, and open it onto a land that is eccentric, immemorial, or yet to come (for example, the game of territory and the earth in the lied, or in the romantic artist in general). Still others open assemblages onto abstract and cosmic machines that they effectuate". ${ }^{2}$ Every assemblage, therefore, consists of a horizontal and vertical axis. The horizontal axis is made of bodies and discourses, words and things or knowledge and power or visible and utterable in the Foucaultian sense. That is, the horizontal axis articulates a framework for thinking about the way that ideology acts upon bodies and the way that bodies, in turn, discipline themselves into ideological forms or pull against them. The vertical axis depicts factors of stabilization and stability, but also factors of change, meaning that this is the temporal component of an assemblage, enabling the existence of the line of flight. ${ }^{3}$ Every assemblage is, on the one hand, individual, singular, but on the

tastes, varieties of joy and pain, etc.)". This primarily appears as a dichotomous division of these possibilities (pairs such as male/female, human/nonhuman, etc.), which determines in advance "our perception, affectivity, and thought, imprisoning experience within alreadymade forms, even forms of refusal and struggle". In that respect, the line of flight is the process of deterritorialization, the redistribution of these limited possibilities, which is related to the "unforeseeable creation of new space-times and original institutional assemblages". François Zourabichvili, Deleuze: A Philosophy of the Event, Edinburgh University Press, Edinburgh, 2012, 174-175. Cf. Gilles Deleuze and Félix Guattari, A Thousand Plateaus, Continuum, London and New York, 2004, 147-148, 199-202, 320-323; Leslie Dema, The Inorganic Life of Assemblages: Deleuze and Guattari's "The Geology of Morals", The University of Guelph, 2006, 62-65 (unpublished manuscript).

${ }^{2}$ Gilles Deleuze and Félix Guattari, A Thousand Plateaus, op. cit., 97-98, 556.

${ }^{3}$ Cf. Drew Daniel, The Melancholy Assemblage: Affect and Epistemology in the English Renaissance, Fordham University Press, New York, 2013, 7-11. 
other hand, assemblages can also include the most abstract and singular phenomena, from an individual inorganic entity to the general social entirety, ${ }^{4}$ or in other words: "This notion is larger than structure, system, form, process, etc. An assemblage contains heterogeneous elements, on a biological, social, machinic, gnoseological, or imaginary order." 5

This specific assemblage can be split up into several components, or lines, whose folds and mutual relationships make that assemblage. The first line is the entire 'musical' system - the acoustic material (noise as the research of the relationship between the musical and the nonmusical and their [non]porous boundaries), the listener (the utmost challenging of their capacity to listen, hence depletion of that capacity), and the creator (reassessment of the role and position of the musical creator as a creative agent within and outside the system of music production and consumption). The second line is Merzbow's aesthetics reflected in various images (album covers), articles, interviews, etc., accompanying individual 'albums'. Given that this is a very fruitful artist (with dozens, if not hundreds of 'albums' released since his 'career' has begun), this is also a multiplicity of such accompanying elements, but it is also possible to pinpoint the key characteristic of the acoustic and visual material: masochism. On the one hand, masochism refers to the listener (depletion of the capacity to listen), and on the other, it speaks of a specific aesthetics of existence, as Foucault would put it (the disorganization and, potentially, reorganization of the "everyday' body through masochism). The third line contains everything that I labelled as posthumanism in Merzbow's activities, which can be perceived both in his musical work (the nonmimetic use of animal and natural sounds as material for noise), and in the lifestyle (animal rights activism, vegan diet, etc.). Therefore, this assemblage, consisting of at least three different lines, aims to deconstruct and, eventually, completely obliterate the humanist concept of the human subject/body as the supreme and superior power of action or, in humanist-Darwinist terms ${ }^{6}$ the crown of evolution, replacing it by (in)organic multiplicity.

\footnotetext{
${ }^{4}$ Cf. Manuel DeLanda, A New Philosophy of Society: Assemblage Theory and Social Complexity, Continuum, London and New York, 2006; Manuel DeLanda, A Thousand Years of Nonlinear History, Zone Books, New York, 1997.

5 Félix Guattari, The Anti-Oedipus Papers, Semiotext(e), New York, 2006, 415. Cf. Gilles Deleuze and Claire Parnet, Dialogues II, Columbia University Press, New York, 2007, 69; François Zourabichvili, Deleuze: A Philosophy of the Event, op. cit., 145-148.

${ }^{6}$ I intentionally use the term "humanist-Darwinist", with the stress on "humanist", because there are different interpretations of Darwin's texts. Another perception, aided by Deleuze and Bergson, which is not focused on the human being as the crown of evolution, can be found in: Elizabeth Grosz, Becoming Undone: Darwinian Reflections on Life, Politics, and Art, Duke University Press, Durham and London, 2011.
} 
The emergence of noise as an artistic practice is related to British industrial music (Whitehouse, Throbbing Gristle, SPK), North-American experimental rock (Velvet Underground and no wave), free jazz (Albert Ayler, the late works of John Coltrane, improvisational collectives from the 1970s) and European post-war electronic composing and musique concrète. ${ }^{7}$ Some also relate it to the ideas and practices of John Cage, Arnold Schönberg, Edgard Varèse, Luigi Russolo, ${ }^{8}$ but also to Japanese traditional music, punk and popular electronic music. ${ }^{9}$ With all these influences, Japanese noise has developed from the 1970s, and the main exponents beside Merzbow, such as Masonna, Keiji Haino, MSBR, Boredoms, designed and determined their practices and styles during the 1980s, reaching a peak in the late 1990 s and the early $21^{\text {st }}$ century.

${ }^{7}$ David Novak, Japan Noise: Global Media Circulation and the Transpacific Circuits of Experimental Music, Columbia University, 2006, 30 (doctoral dissertation).

8 Paul Hegarty, "Brace and embrace: Masochism in noise performance", in: Marie Thompson and Ian Biddle (eds.), Sound, Music, Affect: Theorizing Sonic Experience, Bloomsbury, London, 2013, 133-134. We should also note the fact that genealogies of noise are not exactly the same everywhere. Thus, noise music in the United States of America developed primarily under the influence of no wave and punk music, together with the "hippie experimentalism of the West Coast", while in Europe there is a clear influence of industrial music from the 1970s and 1980s. Cf. ibid. In that respect, Japanese noise is the most elusive, because its main exponents speak about various influences, ranging from European avant-garde and American experimental rock to Japanese traditional music. Cf. David Novak, Japan Noise..., op. cit. Novak also makes a distinction between noise and "noisy music", whereas he describes noise as "dissonance, a discordant sound that disturbs appreciation. But beyond being merely unintelligible and unwanted, noise is also an interruption, a symbol of broken communication. As the opposite of a content-laden 'signal,' the mere presence of noise interferes with the transmission of sonic meaning... Noise is the opposite of shared public consensus, as resistance to social order: this noise relates to the ideologies of democracy in the public sphere and systems of incorporation in state and media contexts, both locally and in the face of globalization and globalist dreams of universal participation. Noise is the opposite of music, as the nemesis of beautiful or desirable things admissible as musical sounds; this noise pertains to aesthetics and affective evaluations of experience. Noise is the opposite of communication, against meaning and the transmission of information; this noise is part of a binary signal-to-noise dialectic that embeds sonic communication in a ratio of meaningful versus interruptive or obscuring material. Noise is the opposite of classification, in its refusal of categorical objectivity; this noise stands at the margins of musical style and the discursive emplacements of genre. Noise is the opposite of the natural world, and its silence; this noise emerges from the urban industrialized environment and in the experiential conditions of technology... The breakdown of performance time into song-like sections, the presence of more than one or two performers, a lack of timbral 'harshness', the use of recognized musical instruments, and the presence of melody or rhythm are all markers of sound more likely to be classified as 'noisy music' than noise". David Novak, ibid., 133-134, 2, 136.

9 Paul Hegarty, Noise/Music: A History, Continuum, London and New York, 2007, 138. 
Around 1980, Masami Akita, after having already played the guitar and drums in experimental and free rock bands, started performing with a set of guitar effects pedals and junk electronics, i.e. sounds produced randomly and automatically by electronic machines. The performances consisted of pure, raw, coarse sound, without instruments. Akita conceived his acoustic creations as overburdening the other music, as transformations of the already existing information during the process of total distortion: "It's an overload of information: every music can be Noise, if I make its volume overload. So maybe it's a kind of overload of music. I don't know, but this overload feeling of the sound is what makes it clear for me. So I'm making this feeling produce." ${ }^{10}$ Merzbow's system of altered electronics literally overloads the original sounds, transforming them into a mass of distorted microphonics, and the aim of such acoustic practice is "sound as political and erotic weapon" (including the album titled Music for Bondage Performance and a book on kinbaku, Japanese techniques of bondage). ${ }^{11}$

It is very difficult to describe Merzbow's noise. The words most often used are 'raw', 'rough', 'difficult' (both in the sense of listening and noise level), 'violent', 'metallic' and so on. This is one of the typical descriptions, referring to the number "Looping Jane" from the album Amlux, released in 2003: "Looping Jane' is sixteen minutes that progresses through a number of separate "movements,' building from a field of slow-moving deep drones into full-out roaring noise, then evolving into mechanical overlapping droning sounds that buzz and move in a hypnotic way. [...] Later the track gets pared down a bit more, leaving a bed of repeating low-end drones over which Akita throws a variety of other sounds, twisting and stretching instances of static and synthetic high-end sound sources into pricks and stabs of noise."12 Or let us take the following section from the review of the 2008 album Anicca: "Digital textures are blended seamlessly with blistering feedback that seems to sweep in and out of the mix. [...] A destructive mixture of laptop-based sound, combined with intense amplifier noise and junk-guitars pad out the sound, increasing the density of the mix and creating wild and engaging soundscapes." 13

This inability to describe and to find adequate language has its reason. Noise is based primarily on the act of listening (and its depletion), i.e. the reception of sound as a physiological reaction takes precedence over listening as the

\footnotetext{
${ }^{10}$ Quoted in: David Novak, Japan Noise..., op. cit., 183.

${ }^{11}$ Quoted in: ibid., 139.

12 Mason Jones, "Merzbow - Amlux", http://www.dustedmagazine.com/reviews/518, accessed on 19 August 2013.

${ }_{13}$ Starcorea, "Merzbow - Anicca", http://www.sputnikmusic.com/review/28808/MerzbowAnicca/, accessed on 19 August 2013.
} 
Filipović, A.: Musica Inhumana: Towards the Posthumanistic Ethical ... (86-101)

recognition of tonal utterances based on language. As David Novak says, "The embodied social interaction of a dance music concert discourages private aesthetic contemplation, while a symphony concert hall achieves its effect of mental elevation in part by enforcing bodily stillness. But because extreme volume is both heard as sound and felt as soundwaves, loud music blurs the division between mind and body in a synaesthetic moment of transcendence." ${ }^{14}$ Noise engulfs the listener in extremely loud sound and creates a space of overwhelming intensity. This sound space of noise is dominated by an involuntary physiological reaction to the sound that compels the listener to face their own body: "You can feel your whole body just go into shock when they start - the sound fills your mind completely and you can't think. At first you're just shrinking back, until you overcome that and let it go, and then you're in it and you're just being blown away." ${ }^{15}$ The effect of high loudness is felt directly as visceral individual immersion in sound, and it differs from a normative musical experience by not separating aesthetic contemplation and corporeality. Noise is physiologically 'extreme' because its sound is located on the extremes of individual sensory perception, and the extended sound range of a CD helps emphasize these qualities on noise albums. Thus, Merzbow's album Venereology, in its time, was banned in the United States because it violated the laws about the permitted dynamic levels on a CD. ${ }^{16}$

A particular aspect of Merzbow's noise creativity is the nonmimetic use of animal sounds. Thus, in a six-disc collection Houjoue from 2006 - especially on the fourth disc, in the numbers "Frog Variation 0505" and "Animal Magnetism Variation 0305 " - he uses digitally processed sounds of animals, actually his pets, including small show chickens, pigeons, ducks and other animal sounds he had sampled previously. As he said in an interview about the Houjoue collection, the theme of these six discs is related to the "vegetarian history of the early Japanese", ${ }^{17}$ and while working on it, he was also writing the book Cruelty Free Life. Houjoue is a "ceremony of freeing captured animals", and in the $7^{\text {th }}$ century A.D. the emperor prohibited the consumption of animal meat, including fish and seafood. Some of the sounds he used to create this collection include the sound of hens pecking, because "they are always pecking some object, for the care of their beaks". ${ }^{18}$ Another album from 2006, titled Minazo,

\footnotetext{
${ }^{14}$ David Novak, Japan Noise..., op. cit., 227.

15 Quoted in: ibid., 227.

16 Ibid., 242

17 Roger Batty, “Animal Instincts - Interview with Masaki Akita”, http://www.musiquemachine.com/articles/articles_template.php?id=73, accessed on 25 August 2013.

18 Ibid.
} 
which is, as he personally said, more improvisatory, was recorded as a homage to Minazo, a giant elephant seal which shortly before that had died in a Japanese zoo. Minazo is shown on the album cover. Animals are featured on the covers of many other albums. Thus, Merzmorphosis, a ten-disc collection from 2012 shows turkeys; Kibako, from the same year, shows insects and flowers; Samidara, from 2013, shows a strange splice of rabbit and human; Jigokuhen, from 2011, shows a grouse; and Surabhi, from the same year, shows Indian holy cows. The album Dolphin Star was recorded in 2008 as a sign of protest against the killing of thousands of dolphins every year in a Japanese prefecture. By appropriation of animal sounds and by covers that depict the (non)human in the most diverse ways, Masami Akita wants to point to the bearing of a human being upon anything that is not a human being. Since he is a radical vegan and animal rights activist, these elements of his artistic practice are an attempt at changing the human attitude towards the environment, i.e. they suggest the possibility of building different ethics and aesthetics which will not be anthropocentric (nonmimetic aspect of the use of animal sounds). In fact, if extreme noise is also taken into account, then one can speak of the specific posthumanistic ethical and aesthetical policy of his artistic practice.

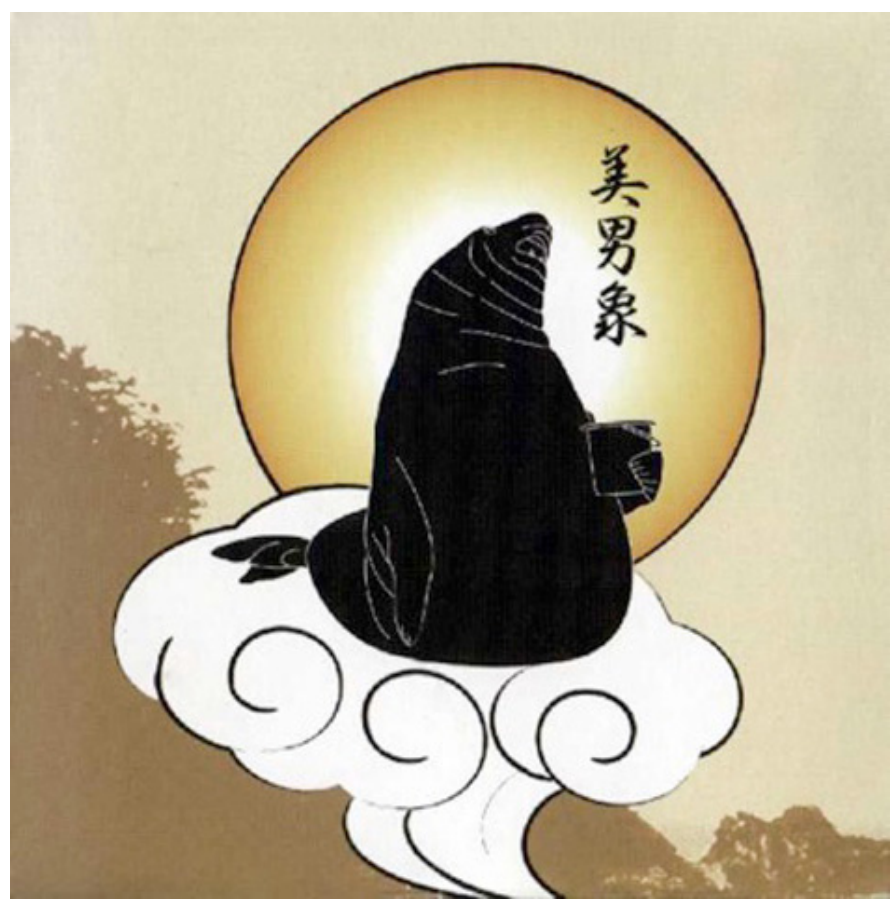

Minazo - Volume One, Important Records, 2006. 
Filipović, A.: Musica Inhumana: Towards the Posthumanistic Ethical ... (86-101)

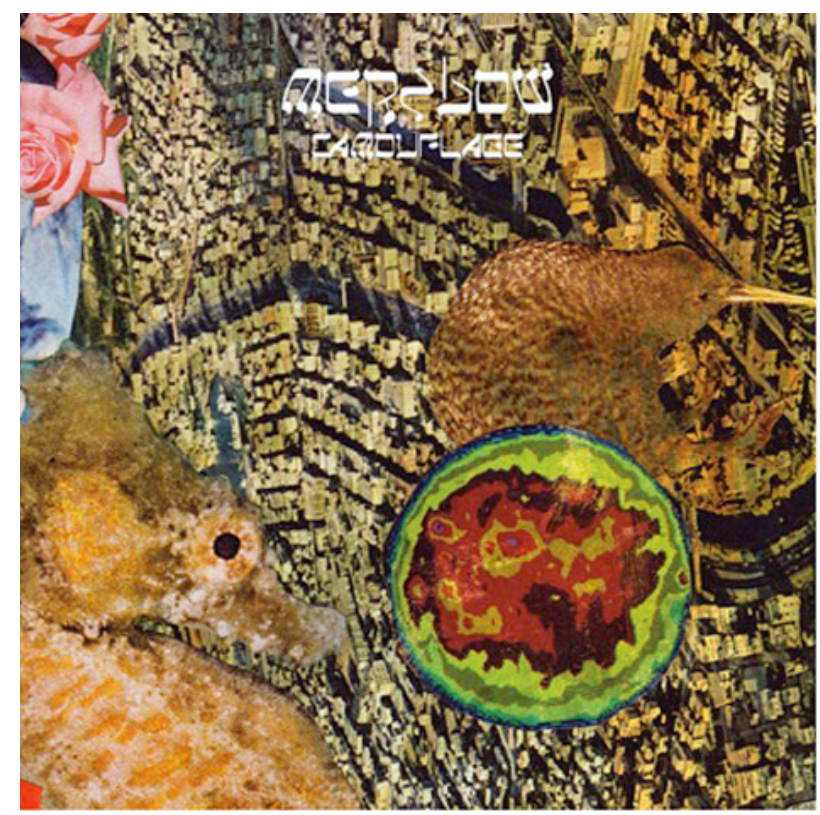

Camouflage, Essence Music, 2009.

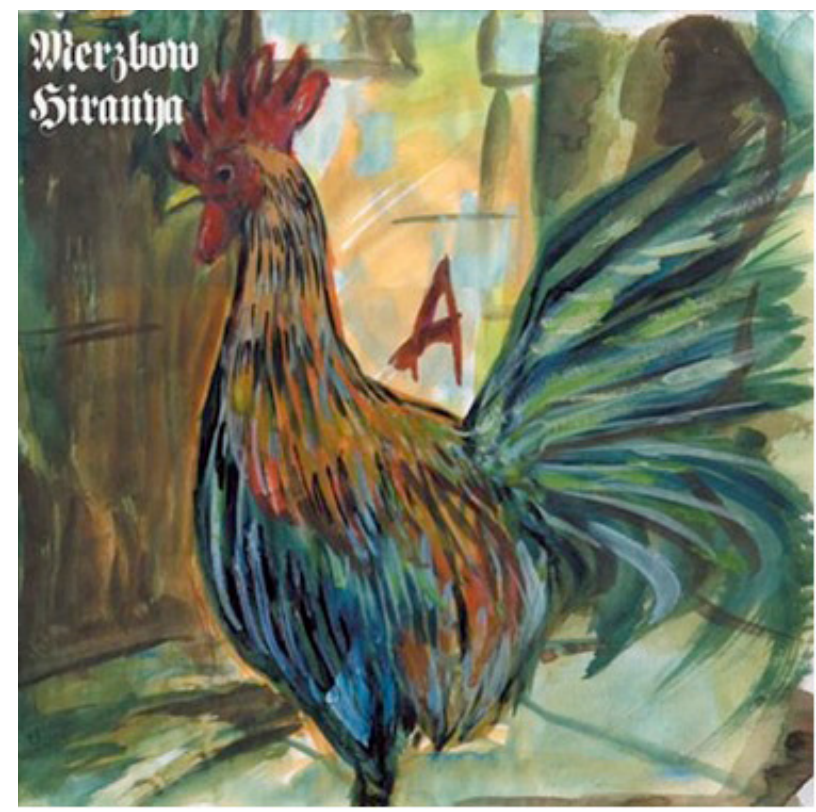

Hiranya, Noiseville, 2009. 


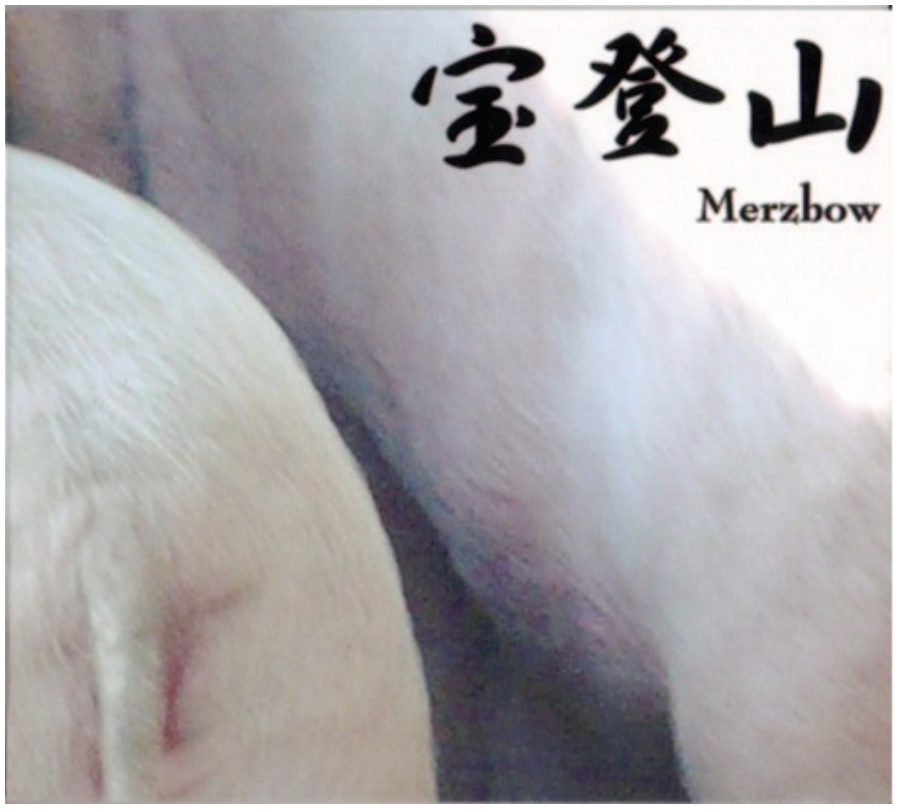

Hodosan, Vivo, 2008.

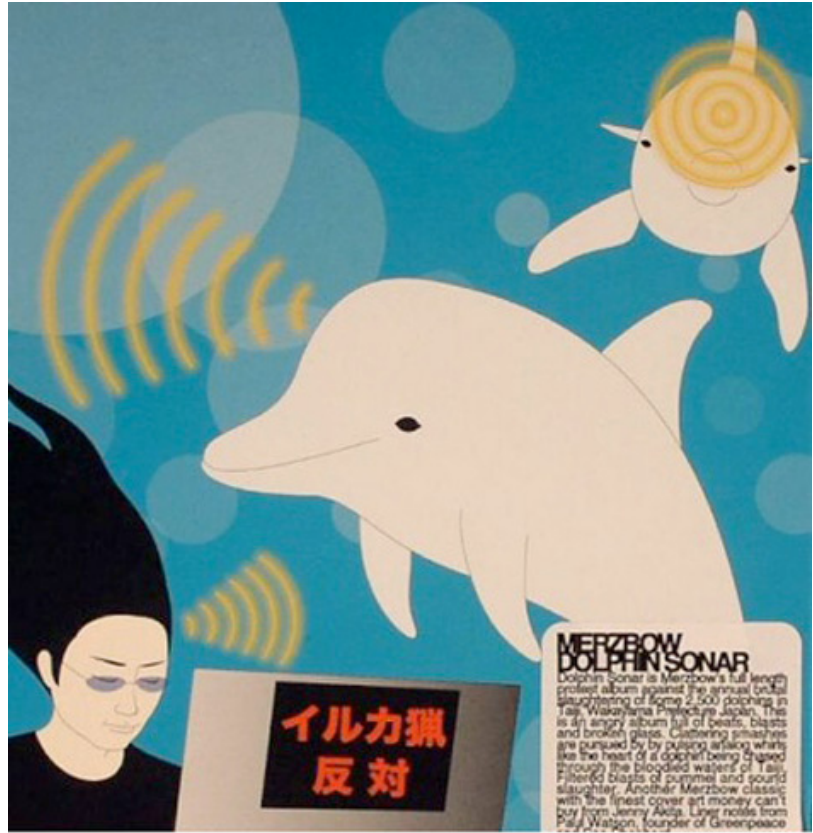

Dolphin Sonar, Important Records, 2008 
As I have already explained, the extreme loudness of sound, both in the recorded material and in live performances, causes overcharge and, eventually, depletion of the capacity to listen. The relationship established between the listener or the audience and the performer or the acoustic material can be interpreted as a sadomasochistic relationship. ${ }^{19}$ Here I will be relying on the Deleuzian understanding of masochism, most of all because its approach to the body is different than that of Freudian (and Lacanian) psychoanalysis, limited by the Oedipal triangle which in fact constrains it to humanistic (binary) thinking. ${ }^{20}$ There is also a different interpretation of noise, using primarily Bataille's philosophies of abjection and transgression. In that case, noise is understood as the ethics of excess, as something rejected and formless which ecstatically deconstructs subjectivity. ${ }^{21}$ The problem in this interpretation of noise is that it is too general, i.e. its specific qualities cannot include and describe various phenomena within noise music. ${ }^{22}$ Hereby I mean that Merzbow is a singular assemblage containing multiple folded lines, each of them in turn having its own specific qualities. Also, these two approaches have different policies. The transgressive-ecstatic approach, unlike the masochistic-contractual, lacks coldness, i.e. a particular kind of sobriety with which problems in creating lines of flight should be addressed. ${ }^{23}$

19 Reinhold Friedl, "Some Sadomasochistic Aspects of Musical Pleasure", Leonardo Musical Journal, Vol. 12, 2002, 30.

20 "Freud's understanding of masochism is founded on the familial relations of the Oedipal drama. Here, femininity is constituted as passive, whereas masculinity is constituted as active. The father's dominance makes him the biggest threat to the male child. He has the power to castrate, imbue the son with lack, and turn him into a woman like his mother. While lack is deemed natural and normal in the female, it is not so in the male. The male child's castration anxiety may therefore develop into masochist perversion. The male child's guilt and fear of castration leads him to assume a passive role in order to placate the father and win his love.... But according to Freud, masochism as a sexual preference or desire in the male adult cannot stand by itself. It needs an opposite. Masochism needs sadism. At any time, the masochist can turn into a sadist. But not only are all sadists ex-masochists. Both masochists and sadists are sadomasochists as both desires are embodied within one and the same individual." Torkild Thanem and Louise Wallenberg, "Buggering Freud and Deleuze: toward a queer theory of masochism", Journal of Aesthetics \& Culture, vol. 2, 2010, 2.

${ }_{21}$ Paul Hegarty, "Noise as Weakness", http://www.dotdotdotmusic.com/hegarty2.html, accessed on 28 August 2013. Other essays should be mentioned too, such as "Noise as Ethics of Excess", "Merzbow and the End of Natural Sound", "Theory and Japanese Noise Music".

22 Lines of flight must be considered from the aspects of the specific character of each of the lines, their relative importance, mutual immanence and dangers that are distinct for each individual line. Cf. Gilles Deleuze and Félix Guattari, A Thousand Plateaus, op. cit., 225-228. ${ }^{23}$ Here we are talking about the problem of a sensory impression and its construction as the means for creating an opportunity for a line of flight. Given that every kind of art deals with creating a sensory impression, i.e. with their construction, this construction does not ema- 
Deleuze severs the connection between sadism and masochism, and credits masochism with a contractual nature by which it subverts power relations between individuals. The masochist is the one with the power, having in fact the power of action, contrary to the typical Freudian concept where the masochist is just the passive recipient in a sadomasochistic relationship in which the general power and power of action belong to the sadist. Deleuze deconstructs the Freudian concept of sadomasochism by offering a different aetiology of masochism. Contrary to the Freudian understanding that the father is the one who castrates, thus becoming the primary figure in the child's life, Deleuze takes the mother as the crucial figure, making masochism reach the pregenital and symbiotic phase in the mother-child relationship. The mother is an ambivalent figure in the oral phase of development because, in Deleuze's opinion, she, and not the father, is the one who can punish, thus being the primary source of authority due to the child's fear of abandonment. The source of masochism is this fear of abandonment, and a masochist re-enacts scenarios of hiding and exposing, disappearing and appearing, seduction and abandonment, combined with pain in order to punish and reject the father symbolically. For Deleuze, this means that masochism cannot be an issue of the castration fear because the primary and crucial figure is the mother, not the father. By this move, Deleuze cancels Freud's Oedipal scenario because a masochist, on the one hand, equates the mother figure with the law, while on the other, eliminates the father from the symbolic system. The re-enactment of the mother-child relationship in masochist scenarios includes the re-enactment of the pregenital and symbiotic relationship between a mother and a child. However, the fantasy about the total symbiosis and fusion of these two sides in the relationship can be fulfilled only at the imaginary level, because a real amalgamation implies death. Thus, death becomes the final resolution of the masochist fantasy, necessitating the deferment of orgasm. It must be postponed for some undetermined future so that the masochist would survive, which makes waiting and repetition the determining categories of masochism.

nate from something irrational, but only from careful preoccupation with the specific problem: "You have to keep enough of the organism for it to reform each dawn; and you have to keep small supplies of significance and subjectification, if only to turn them against their own systems when the circumstances demand it, when things, persons, even situations, force you to; and you have to keep small rations of subjectivity in sufficient quantity to enable you to respond to the dominant reality. [...] This is how it should be done: Lodge yourself on a stratum, experiment with the opportunities it offers, find an advantageous place on it, find potential movements of deterritorialization, possible lines of flight, experience them, produce flow conjunctions here and there, try out continuums of intensities segment by segment, have a small plot of new land at all times. It is through a meticulous relation with the strata that one succeeds in freeing lines of flight." Ibid., 178. 
Filipović, A.: Musica Inhumana: Towards the Posthumanistic Ethical ... (86-101)

The key differences between sadism and masochism, and consequently between various body policies supported by these two phenomena, are the following: "(1) Sadism is speculative-demonstrative, masochism dialecticalimaginative; (2) sadism operates with the negative and pure negation, masochism with disavowal and suspension; (3) sadism operates by means of quantitative reiteration, masochism by means of qualitative suspense; (4) there is a masochism specific to the sadist and equally a sadism specific to the masochist, the one never combining with the other; (5) sadism negates the mother and inflates the father, masochism disavows the mother and abolishes the father; (6) the role and significance of the fetish, and the function of the fantasy are totally different in each case; (7) there is an aestheticism in masochism, while sadism is hostile to the aesthetic attitude; (8) sadism is institutional, masochism contractual; (9) in sadism the superego and the process of identification play the primary role, masochism gives primacy to the ego and to the process of idealization; (10) sadism and masochism exhibit totally different forms of desexualization and resexualization; (11) finally, summing up all these differences, there is the most radical difference between sadistic apathy and masochistic coldness." ${ }^{24}$

These determinants - among which I stress reiteration and de/resexualization as crucial - give rise to a particular ontology of desire. Namely, masochism causes the change of relationship between reiteration and the principle of pleasure: "Instead of repetition being experienced as a form of behavior related to a pleasure already obtained or anticipated, instead of repetition being governed by the idea of experiencing or reexperiencing pleasure, repetition runs wild and becomes independent of all previous pleasure. Pleasure is now a form of behavior related to repetition, accompanying and following repetition, which has itself become an awesome, independent force... Pleasure and repetition have thus exchanged roles, as a consequence of the instantaneous leap, that is to say the twofold process of desexualization and resexualization... Pain in this case has no sexual significance at all; on the contrary it represents a desexualization which makes repetition autonomous and gives it instantaneous sway over the pleasures of resexualization." ${ }^{25}$ Pleasure, Deleuze says writing about Foucault, interrupts the immanent process of desire, it comes to interrupt the positivity of desire and the constitution of its field of immanence, ${ }^{26}$ meaning that, in masochism, repetition (with a difference), ${ }^{27}$ i.e. desire as opposed to pleasure, creates

\footnotetext{
${ }^{24}$ Gilles Deleuze, Coldness and Cruelty, Zone Books, New York, 1987, 134.

${ }^{25}$ Ibid., 120.

26 Žil Delez, "Želja i zadovoljstvo" [Gilles Deleuze, "Désir et plaisir"], trans. Andrija Filipović, QT: Časopis za kvir teoriju i kulturu, No. 5-6, 2011, 60.

${ }^{27}$ For more on bare repetition and the repetition of difference or with difference, as funda-
} 
lines of flight from the organization of the body and the body as an organism: "Désir ne comporte aucun manque; ce n'est pas non plus une donnée naturelle; il ne fait qu'un avec un agencement d'hétérogènes qui fonctionne; il est processus, contrairement à structure ou genèse; il est affect, contrairement à sentiment; il est 'haecceité' (individualité d'une journée, d'une saison, d'une vie), contrairement à subjectivité; il est événement, contrairement à chose ou personne. Et surtout il implique la constitution d'un champ d'immanence ou d'un 'Corps sans Organes', qui se définit seulement par des zones d'intensité, des seuils, des gradients, des flux. Ce corps est aussi bien biologique que collectif et politique; c'est sur lui que les agencements se font et se défont, c'est lui qui porte les pointes de déterritorialisation des agencements ou les lignes de fuite." ["For me, desire does not comprise any lack; neither is it a natural given; it is but one with an assemblage of heterogeneous elements which function; it is process, in contrast with structure or genesis; it is affect, as opposed to feeling; it is 'haecceity' (individuality of a day, a season, a life), as opposed to subjectivity; it is event, as opposed to thing or person. And above all it implies the constitution of a field of immanence or a 'body without organs', which is only defined by zones of intensity, thresholds, gradients, flux. This body is as biological as it is collective and political; it is on this body that assemblages make and unmake themselves, it is this body which bears the points of deterritorialization of the assemblages or lines of flight."'] ${ }^{28}$

Masochism as a contract producing de/resexualization of the body is a kind of strategy in the sense of Foucault's thesis on sadomasochism as the erotization of power, i.e. the erotization of strategic relationships for creating pleasure or "l'utilisation d'un rapport stratégique comme source de plaisir (de plaisir physique)" ["the use of a strategic relationship as a source of pleasure (physical pleasure)"]. ${ }^{29}$ Since the nature of masochism is contractual or strategic, this is a multi-part relationship, such as the relationship between a performer and the audience, but also the relationship of the individuals within the audience. The performer and the audience need each other to create a masochistic noise assemblage. In this regard, the differences in public performances of various noise artists are interesting. On one side there are performers such Masonna, Hijokaidan, Hanatarash and Incapacitants, who actively move over the stage

mental notions of Deleuze's philosophy of difference, cf. Žil Delez, Razlika i ponavljanje [Gilles Deleuze, Différence et répétition], trans. Ivan Milenković, Fedon, Belgrade, 2009.

${ }^{28}$ Cf. Žil Delez, “Želja i zadovoljstvo", op. cit., 59.

${ }^{29}$ Cf. Mišel Fuko, "Seks, moć i politika identiteta" [Michel Foucault, "Sexe, pouvoir et la politique d'identité"], trans. Andrija Filipović, QT: Časopis za kvir teoriju i kulturu, No. 5-6, 2011, 241-242. 
Filipović, A.: Musica Inhumana: Towards the Posthumanistic Ethical ... (86-101)

and react expressively to every sound produced, while on the other there are performers such as Merzbow and MSBR, who are calmly seated behind their equipment and, in fact, often invisible during the performance. The difference in these two approaches to performing noise is crucial. Active expressivity strives to influence the listeners/spectators by a feedback, expecting them to take part in producing the atmosphere of the performance, while nonexpressive performances break all immediate and 'live' relationships between the performers and the audience, thus at the same time dismissing the phenomenological aspect of the entire event. The active, expressive performance of noise builds what Merleau-Ponty called "double sensation" of the body: "The body catches itself from the outside engaged in a cognitive process; it tries to touch itself while being touched, and initiates a kind of reflection which is sufficient to distinguish it from objects." ${ }^{30}$ However, the problem with this is that the human subjectivity is still left intact. ${ }^{31}$ Merzbow's inexpressiveness has precisely the opposite effect. Deprived of any reference in the form of the performer as the focal point of the performance, the spectator/listener remains confronted only with sound, which all the more effectively depletes the receptive capacity of bodily sensory organs. Inexpressive performance is colder and crueller, as the title of Deleuze's book on masochism reads.

Given the bodies reticulated with relations of power and knowledge, the strategic nature of the masochistic depletion of bodily capacities leads also to a sort of posthumanistic aesthetics of existence. The aesthetics of existence is a notion that Foucault developed in his last texts. It is a complex concept of subjectivization through the relationship of the self with itself and others (and the Other that is not necessarily human) under the conditions in which this self was produced by "rapports de pouvoir qui passent à l'intérieur des corps" ["power relations permeating a body"],,$^{32}$ thus being normalized and, ultimately, made human. At the end of Les mots et les choses [The Order of Things], Foucault wonders if there will be an end to 'man', ${ }^{33}$ bearing in mind the humanistic con-

\footnotetext{
${ }^{30}$ Quoted in: David Novak, Japan Noise, op. cit., 216.

${ }^{31}$ For more on the problematic retaining of the human in phenomenology through transcendental subjectivity which boils down to a doxa reticulated with capitalist power relations, cf. Žil Delez i Feliks Gatari, Šta je filozofija? [Gilles Deleuze et Félix Guattari, Qu'est-ce que la philosophie?], trans. Slavica Miletić, Izdavačka knjižarnica Zorana Stojanovića, Sremski Karlovci, 1995, 184, 188.

${ }^{32}$ Mišel Fuko, "Odnosi moći prožimaju telo" [Michel Foucault, "Les rapports de pouvoir passent à l'intérieur des corps"], trans. Vedrana Veličković, QT: Časopis za kvir teoriju $i$ kulturu, No. 5-6, 2011, 192-201.

33 "Si ces dispositions venaient à disparaitre comme elles sont apparues, si par quelque événement dont nous pouvons tout au plus pressentir la possibilité, mais dont nous connaissons
} 
cept of human nature, while Deleuze somewhat later adds and clarifies: "The death of man is in fact a very simple and precise theme, which Foucault takes over from Nietzsche but develops in a very original way. It is a question of form and forces. Forces are always interacting with other forces. Given human forces (like having an understanding, a will...), what other forces do they come into play with, and what is the resulting 'composite' form? [...] It is in the nineteenth century, rather, that human forces confront purely finitary forces - life, production, language - in such a way that the resulting composite is a form of Man. And, just as this form was not there previously, there is no reason it should survive once human forces come into play with new forces: the new composite will be a new kind of form, neither God nor man. Nineteenth-century man, for example, confronts life and combines with it as the force of carbon. But what happens when human forces combine with those of silicon, and what new forms begin to appear?" 34 The masochistic depletion of a normalized body leads to the disruption of the subjectified body and, thus, to the 'death' of man, i.e. it leads to the re-conceptualization of the human body, due to which it can no longer be dualistically structured (if we follow the Enlightenment-Rationalist line of thought), nor can its development be linearly conceptualized as in Freudian psychoanalysis. Namely, Freud ascertained the chronological sequence from the oral to the anal to the genital/phallic phase, ascribing to the final one the crucial importance in the formation of the personality. The masochistic relocation of the erogenous zones from the genitals and/or anus to the entire body usurps the normative understanding of the personality development and makes it possible to enjoy one's own body in a way different from the one that Freud offered, which is, among other things, the basis of humanism. ${ }^{35}$ In Félix Guattari's words, this is relocation of stress from symbolic castration, being lived as

pour l'instant encore ni la forme ni la promesse, elles basculaient, comme le fit au tournant du XVIII ${ }^{\mathrm{e}}$ siècle le sol de la pensée classique, - alors on peut bien parier que l'homme s'effacerait, comme à la limite de la mer un visage de sable." ["If those arrangements were to disappear as they appeared, if some event of which we can at the moment do no more than sense the possibility - without knowing either what its form will be or what it promises were to cause them to crumble, as the ground of Classical thought did, at the end of the eighteenth century, then one can certainly wager that man would be erased, like a face drawn in sand at the edge of the sea."] Cf. Mišel Fuko, Riječi i stvari [Michel Foucault, Les mots et les choses], trans. Nikola Kovač, Nolit, Belgrade, 1971, 425.

34 Cf. Žil Delez, Pregovori 1972-1990 [Gilles Deleuze, Pourparlers 1972-1990], trans. Andrija Filipović, Karpos, Loznica, 2010, 150.

35 For more about building linearity as a way of orientation and the reconstitution of a 'human' body, and about what it means not to follow the usual standardized linear motion in everyday life, cf. Sara Ahmed, Queer Phenomenology: Orientations, Objects, Others, Duke University Press, Durham and London, 2006. 
Filipović, A.: Musica Inhumana: Towards the Posthumanistic Ethical ... (86-101)

post-Oedipal submission, to "contingent choices" which lend existential consistency to new pragmatic fields: "Investigations must give special attention to the singular virtues of semiotic links that support such choices (ritournelles, facial features, becoming-animals, etc.). In parallel to their semiotic functions of signification and designation, they develop an existential function that catalyzes new universes of reference. [...] It will focus on unfolding innumerable incorporeal, indivisible materials that, as the experience of desire has taught us, are capable of carrying us far beyond ourselves and far beyond territorial encirclements, towards unexpected, unheard-of universes of possibility." ${ }^{36}$

I have underscored, on the one hand, a special way of establishing a relationship with the acoustic material (masochistic contractual relationship); on the other, there are specifically aesthetic lines (the nonmimetic use of animal sounds in digital noise); while the third aspect is the ethical line, i.e. the line of aesthetics of existence (the vegan lifestyle). By folding these three lines - the depletion of the basic capacities of a human body, establishing a relationship with the silicic and the animal, a specific attitude of self towards itself and other - a special aesthetics of existence is built, leading to the potential establishing of posthumanistic subjectivity. In other words, Masami Akita opens the lines of flight in the process of becoming-other (becoming-Merzbow?), thus pointing to a direction one could take in order to resist the power relations: the destruction of the humanistic anthropocentric human subject, or decentralization of the human in its relationship with the evolutionary, technological and ecological coordinates, ${ }^{37}$ and giving way to the (in)organic multiplicity that constitutes the chaosmos.

Translated by Goran Kapetanović

\footnotetext{
${ }^{36}$ Félix Guattari, "Entering the Post-Media Era”, in: Félix Guattari, Soft Subversions: Texts and Interviews, 1977-1985, Semiotext(e), Los Angeles, 2009, 304-305.

37 Carry Wolfe, What is Posthumanism?, University of Minnesota Press, Minneapolis and London, 2010.
} 
